\title{
Digital repository of the University of Belgrade - Faculty of Chemistry
}

UDC $027.7(497.11): 004.738 .5$

DOI 10.18485/infotheca.2020.20.1_2.8

ABSTRACT: The paper presents the principles underlying the functions of the Cherry digital repository at the University of Belgrade - Faculty of Chemistry, and the Innovation Center, and explains why it was decided to use the DSpace software for the first repository of institution. Researchers' questions were considered during procedures of depositing new items in Cherry, as well as the answers provided by librarians during administrative data control. The research part of this paper deals with the repository visit statistics based on Google Analytics and the conclusions that lead to the main goal - to increase the visibility and potential citations of research outputs.

KEYWORDS: Cherry, digital repository, open science, citation, Faculty of Chemistry, Library

PAPER SUBMITTED: 10 October 2020 PAPER ACCEPTED: 2 December 2020
Ana Đorđević

anadj@chem.bg.ac.rs

University of Belgrade, Faculty of Chemistry

Library

Belgrade, Serbia

\section{Introduction}

The expansion of scholarly publishing in an electronic format has brought great changes and challenges in the $21^{\text {st }}$ century. On the one hand, the complete change in the concept of the dissemination of scholarly papers has made the whole process easier due to the fact that electronic versions of papers are easier to distribute, but on the other hand, it has significantly limited the rights of authors and the balance regarding funding. The easier distribution of scholarly papers in an electronic format is sometimes merely an illusion because many publications are behind a paywall. In practice, the author of a paper often transfers copyright to the publisher by signing a standard contract. As soon as the contract is signed by both parties, the 
publisher gains the right to determine the availability of the publication because the publisher has formally become the owner of the publication in question. The problems regarding publishing policies have been identified globally, and there seems to be only one solution - open science.

Librarians in the Republic of Serbia have been promoting open access to scholarly literature for many years. Specific guidelines for local publishers of scholarly journals were presented, among other things, within the project "Revisiting Open Access Journal Policies and Practices in Serbia". ${ }^{1}$ The project was implemented at the National Library of Serbia, and the results are presented in the study "Open Access Journals in Serbia: Policies and Practices". There are about 400 active open access scholarly journals in Serbia $^{2}$. Most journals do not charge Article Processing Charges for publishing, and, at the same time, they do not deny access to the full text of articles. Keeping in mind the growing number of rules adopted in the context of open access to publications at the international level, local journals could become increasingly attractive to international authors thanks to the policy of openness. To achieve this, they should improve their visibility and efficiency on the World Wide Web. Most editors traditionally insist on having a print version of journal issues, but there are also those who make electronic versions available online. Journals that are published only electronically are rare in Serbia (Ševkušić et al., 2017). As far as international publishers are concerned, authors often face the inconvenience of transferring the copyright, while their publications are not publicly available. With the rise of digital repositories, authors have become aware of the importance of green open access as a legal model for presenting their scholarly work to the public. The green route, often referred to as the "self-archiving" route, entails authors submitting manuscripts to journals (subscription-based, gold open access, or hybrid open access) while retaining the right to deposit a version of their work to a digital open access repository (Fry et al., 2016). In order to ensure that self-archiving is carried out in line with legal regulations, the permission of the publisher, which often involves an embargo period, to deposit a specific version of the paper is required. By enabling open access to their papers, authors get the advantage of a greater visibility of their research,

${ }^{1}$ Revisiting Open Access Journal Policies and Practices in Serbia, (retrieved on November 17, 2020).

${ }^{2}$ Based on data collected by the Department for Scientific Information of the National Library of Serbia. The number is not precise due to changes in the editorial policies, which are not always duly notified. 
which can be reflected in increased citation counts. ${ }^{3}$ The advantage of open access for the author's institution is easier credibility and ethical correctness of scientific work. The openness of scientific results encourages critical attitudes and exchange of opinions, which is the starting point in seeking truth, as the only path to knowledge. This advantage was recognized by the University of Belgrade - Faculty of Chemistry, which established the Cherry (CHEmistry RepositoRY) institutional digital repository.

\section{Open science and the role of the publisher}

The Ministry of Education, Science and Technological Development (MESTD) allocates funds for subscriptions to international scholarly literature. The subscriptions cover about 35,000 journals and 180,000 books in the electronic format available through the services of the Serbian Library Consortium for Coordinated Acquisition (KoBSON) (Ђенадић et al., 2020). In addition to full-text databases, citation databases are also available to the research community in the Republic of Serbia. These valuable resources provide great opportunities for the successful research of individuals, but also for the overall success of science in Serbia, which is internationally recognized. The number of papers published by Serbian authors in the most influential international journals is also visible in the "Naši u WoS" database, maintained by the Department for Scientific Information at the National Library of Serbia. The name indicates that the database is created by selecting from the Web of Science only the papers by the authors affiliated with institutions from the Republic of Serbia. It offers bibliographic information about papers indexed in the Web of Science since 2000 to the present. Based on the statistical data for the 2000-2019 period, the number of published papers has increased by almost six times. ${ }^{4}$ The body of scientific information available in the electronic format to the Serbian research community is significant and the usage statistics show that the Kobson portal is highly important for users. The million-access number shows that the KoBSON portal is of great importance to users. At the same time, it indicates that no library, not even the largest in the world, could physically

3 The tables at the end of the paper indicate that the most visited publications in Cherry are available in open access. A large number of studies in the field of library and information science discuss the relationship between citation counts and access type.

${ }^{4}$ The number of papers in 2000 was 1352 , while it was 7868 in 2019. Naši u Wos, (retrieved on November 17, 2020). 
serve such a large number of users (Тимотијевић et al., 2016). It should be kept in mind that KoBSON allows remote access only to the employees of public academic and research organizations, but not outside the borders of the Republic of Serbia. ${ }^{5}$ It is only when researchers cannot access their own publications, but would formally have to buy them, that they become aware that the institutional access provided in the Republic of Serbia is not free of charge, and that they have transferred their copyright to publishers who sell their outputs all over the world. In addition to the annual subscriptions paid through KoBSON, Article Processing Charges are to some degree paid from the public funds provided by the MESTD. To prevent the so-called double dipping and alleviate the burden on the budget for science, different models are being developed all over the world, which have been the subject of debates for many years. A group of publicly funded research organizations, with the support of the European Commission and the European Research Council, have launched an initiative to provide full and immediate open access to scientific publications beginning with $2021 .^{6}$ The initiative cOAlition S was announced on September 4, 2018, with one clear goal-open science, expressed in ten principles:

1. Authors should retain copyright on their publications, which must be published under an open license such as Creative Commons;

2. Members of the coalition should establish strong criteria and requirements for compliant open access journals and platforms;

3. They should also provide incentives for the creation of compliant open access journals and platforms, if such do not yet exist;

4. Publication fees should be covered by the funders or universities, not individual researchers;

5. Such publication fees should be standardized and capped;

6. Universities, research organizations, and libraries should align their policies and strategies;

7. For books and monographs, the timeline may be extended beyond year 2021;

8. Open archives and repositories are acknowledged for their importance;

9. Hybrid open-access journals ${ }^{7}$ are not compliant with the key principle;

${ }^{5}$ Students have access only from the public research organizations connected to the academic computer network (libraries, faculties, institutes).

6 cOAlition S, (retrieved on November 17, 2020).

7 Authors have the right to pay a fee for publishing open-access scientific papers in certain journals of commercial publishers, available only before subscription. These journals are called hybrid journals, (retrieved on November 17, 2020). 
10. Members of the coalition should monitor and sanction non-compliance.

Joining international initiatives in this field, MESTD adopted the Open Science Platform ${ }^{8}$ which defines the rules and guidelines for Serbia, and is intended for all participants in publicly funded scientific research. The platform applies to the results of research projects and programs funded in whole or in part from the budget of the MESTD, Republic of Serbia. In this way, the obligation to deposit publications in repositories was introduced. The Platform also recommends open access to research data. After the adoption of the Platform on July 9, 2018, the process of establishing digital repositories that meet all technical requirements has been accelerated. This process has been particularly intensive in the institutions that have decided to cooperate with the University of Belgrade Computer Center. ${ }^{9}$ There are several reasons why institutions adopt the model developed by RCUB: in the process of establishing a repository all bibliographic metadata that can be harvested from other databases (as well as available full-text publications) are ingested in the repository; the repository is registered in relevant registries and communication with international aggregators is established to ensure visibility; special attention is paid to optimization for Google Scholar (Kosanović et al., 2020). Also, five common features, and perhaps most obvious, are that an institutional repository contains: digital content, community-driven and focused, institutionally supported, durable and permanent and accessible content (Gibbons, 2004).

The first faculty repository in Republic of Serbia developed by the University of Belgrade Computer Center (RCUB) is CHERRY (CHEmistry RepositoRY), a joint repository of the University of Belgrade - Faculty of Chemistry and the Innovation Center. Powered by the DSpace software, where metadata is structured and compliant with the OAI-PMH (Open Archives Initiative-Protocol for Metadata Harvesting), Cherry meets all the technical requirements defined by the Open Science Platform. The main goal of the repository is to increase the visibility of research outputs and projects implemented by the institution, all in accordance with European and national open science guidelines. In addition to increased visibility, higher citation rates of deposited publications have been observed, which cannot be discussed in greater detail in the current phase of research. As a kind of virtual library, the repository collects monographs, scholarly papers, research data, doctoral theses, master's theses and bachelor's theses, as well as all other

\footnotetext{
${ }^{8}$ Open Science Platform, (retrieved on November 17, 2020).

${ }^{9}$ List of nineteen realized repositories, (retrieved on November 17, 2020)
} 
documents that the academic staff and students want to share. An unusual request that was received was to enable the depositing of all issues of the student magazine Pozitron. ${ }^{10}$ When Cherry was established, the initial import by RCUB took 2599 records from the index databases, out of which 1804 were with the full text. Today, Cherry contains 4150 records, out of which 3540 are supplied with full-text files. ${ }^{11}$ The goal is to supply each bibliographic record with the corresponding (full-text) file. New deposits without full text are discouraged, and the existing records are supplied with full-text files with the help of authors.

DSpace is an open-source software package that offers digital asset management tools. It is mainly used by academic and corporate non-profit organizations to create and manage their institutional repositories (Kurtz, 2010). The repositories powered by this most commonly used repository software account for $43 \%$ of all repositories registered in OpenDOAR ${ }^{12}$ (Rajović et al., 2018). All library systems strive for universal interoperability in collecting and sharing metadata. The advantage of the system is mostly reflected in the open code, but also in the interoperability with other repositories, which is achieved due to the adherence to compatible metadata standards and OAI-PMH. Once metadata for a particular object is entered in the repository it should be easily searchable, accessible, readable and portable. Open access platforms adopt OAI-PMH as a standard in communication and a key to interoperability. In the case of Cherry, this means that once deposited, metadata is easily distributed to various platforms, such as Google Scholar, BASE, CORE, OpenAIRE, WorldCat and Unpaywall. Once the repository is registered with aggregators as a data provider, the metadata will be automatically harvested and displayed on other portals in relatively regular time intervals. Currently, only CORE downloads open access full texts from repositories, along with metadata. This is a principle that enables greater visibility of scientific results. Cherry is also registered in registers of open access repositories - OpenDOAR ${ }^{13}$ provides information on sites that fully embrace open access to fulltext resources that are of use to academic researchers (Kruesi et al., 2019) and in ROAR ${ }^{14}$ which also contains thousands

10 Pozitron, (retrieved on November 17, 2020)

11 Between November 28, 2018 when Cherry was established, and November 17, 2020.

12 Insight into the current usage statistics is available on the website: Statistics of DSpace open-source software package using, (retrieved on November 17, 2020)

13 OpenDOAR, (retrieved on November 17, 2020)

14 ROAR, (retrieved on November 17, 2020) 
of active repositories of different software, from different geographical areas. DSpace is a complex system with three interfaces, which are user-friendly: one for repository administrators, the second for depositors, and the third for end users who search for information.

\section{Structure of users and administrative part of CHERRY software}

The availability of the interface in English and Serbian (Cyrillic and Latin) with a short description and instructions for users ${ }^{15}$, and this is the first thing to notice on the home page of the Cherry repository. The search of works is performed by the institution within which the collections are located. The University of Belgrade - Faculty of Chemistry currently has six collections (Publications, Supplementary Data, Doctoral theses, Master's theses, Bachelor's theses and the Pozitron magazine), and the Innovation Center has two (Publications and Supplementary Data). It is possible to choose and arrange collections differently in accordance with the needs of the Faculty. Within each collection, search is narrowed by applying filters (publication year, document type, record version, publication rank in the national evaluation system, or subject). Search can also be performed by author name (by entering the last name and then the first name), and there is simple and advanced search for specific terms, or by keywords. The main feature of the search engine is the ability to search full-text files, in addition to metadata fields. The depositor's and administrator's interfaces in Cherry are basically similar, but the administrator has greater privileges in the following functions:

1. Collection organization and layout - ability to check and verify deposits, control access to full text and metadata, organization and deletion collections;

2. User management - manage user groups, all employees at the University of Belgrade - Faculty of Chemistry and the Innovation Center may register. After initiating the registration process, users receive an email with a verification link enabling them to complete the registration process. In Cheery, the administrator normally grants the privilege of only reviewing and depositing new items;

${ }^{15}$ A user manual was presented during the three-day training for the academics and research staff of the University of Belgrade - Faculty of Chemistry and Innovation Center: Cherry User Manual, (retrieved on November 17, 2020). 
3. Curation - the existing records in the repository cannot be modified by users but the administrator can make changes such as adding files (usually PDF), adding new metadata, deleting or modifying metadata, moving records from one collection to another and, if necessary, deleting a complete record;

4. Mapping - if the authors of a paper are from both the University of Belgrade - Faculty of Chemistry, and the Innovation Center, it is necessary to make the relevant record visible in both collections. After depositing in one collection, the record is mapped in the other. Item mapping enables both entities to keep a full record of their publications in their respective collections without creating duplicate records.

5. Statistics - the administrator has access to the visit statistics for individual records, an overview of the most frequently searched terms in a certain period of time and the statistics of procedures for accepting, rejecting or modifying metadata undertaken by the administrator.

Only registered users can deposit new items. After selecting the collection, the user fills in the following fields to describe the publication:

- Authors - in the format "Surname, Name" in the order as listed in the original paper;

- Title - title of the publication;

- Source - the title of the journal or proceedings (in case a paper is deposited), or the title of the book if a chapter is deposited;

- Date of publication;

- Collation - volume, number, home page or article number and end page;

- Identifiers - DOI, ISSN or ISBN, PubMed, COBISS-ID, arXiv, Scopus and WoS. Based on DOI, it is possible to display citation counts from Dimensions ${ }^{16}$ and Altmetric Attention Scores ${ }^{17}$. Altmetric is a platform offering alternative metrics for scholarly papers by tracking online sources, especially social networks, blogs, Wikipedia and other websites. The number of mentioned publications is measured through a weighted arithmetic mean in which the DOI number of the paper is stated and is shown by a graphic illustration in different colors (each color represents a separate platform in which the paper is mentioned). Depending on the source, each mention is multiplied by a certain coefficient. ${ }^{18}$ Dimensions is at certain extent free access ${ }^{19}$ citation database which tracks

$\overline{16}$ Dimensions, (retrieved on November 17, 2020).

${ }^{17}$ Altmetric, (retrieved on November 17, 2020).

18 Altmetric Attention Scores, (retrieved on November 17, 2020).

19 Dimensions, (retrieved on November 17, 2020). 
data from research and academic institutions with a total of over 100 million searchable publication. In addition to scholarly articles, information on research data, patents, projects, clinical trials and public policy documents can be found. Scopus and WoS identifiers are important for displaying citation data within a record.

- Funding information - is entered in the form of machine-readable code for data transfer to the OpenAIRE - European Open Science Infrastructure. Funding information is provided in the format recommended by the OpenAIRE Guidelines for Publication Repositories. ${ }^{20}$

- Type of publication - journal article, book, book chapter, conference object, lecture, doctoral thesis, master's theses, bachelor's thesis, review, working document, preprint, report, annotation, informative article, patent and other as a choice when the document is not classified in any of the above categories;

- Publication version - published, draft, submitted, accepted and corrected;

- Language - multiple publication languages can be selected;

- Summary;

- Keywords - free-style keywords, without controlled dictionary terms;

- Other authorships - in the format "Surname, Name" in the order as listed in the original publication;

- Publishers - in the format "place : publisher";

- Any notes - related to the publication;

- Access - open access, closed access, restricted access and embargoed access;

- License type - Creative Commons licenses.

At metadata input, special attention should be paid that along with metadata, it is necessary to deposit a full-text file. Depending on the type of publication, not all fields are required.

Cherry currently has eighty-eight registered users who can submit their new research outputs, and the process of depositing one publication takes five to twenty minutes, depending on the user's skills. The software is accessible and clear, and the input form has three segments. The process of depositing is explained in great detail during individual and group training for researchers in order to encourage them to deposit their publications regularly.

$\overline{20}$ OpenAIRE Guidelines for Publication Repositories, (retrieved on November 17, 2020); 


\section{Versions of documents and licenses}

In order to comply with the mandate defined in the Open Science Platform, librarians remind researchers of the original function of the repository and the obligation to deposit full-text files within twelve months since the publication. The solution to cases where authors cannot deposit the published versions of papers due to publishers' rights is provided by the so-called green open access. Authors are allowed to deposit the peer-reviewed versions of their articles in the institutional repository immediately or after the embargo period required by the publisher of the journal in which the article is published. ${ }^{21}$ Given that authors from the University of Belgrade - Faculty of Chemistry publish mostly with foreign publishers such as Elsevier, Wiley, Springer, and others whose journals are highly ranked, the Cherry administrator takes special care of the level of availability of such papers before verifying deposits and making full-text available. In such cases, two versions of the document are deposited: the published version, which will permanently remain restricted to the public and available only to registered users, and the accepted version, which has undergone peer-review but has not been copyedited and typeset. Access to supplementary materials, which are not subject to copyright transfer, is often restricted on publishers' websites. For that reason, a third record is formed for supplementary materials or research data and these materials are usually made open access in the repository. The two versions of the paper and the supplementary materials, if available. ${ }^{22} \mathrm{In}$ case of a paper originally published in open access, there is no need to deposit the peer-reviewed manuscript. In this case, only the published version is deposited and is made publicly available. In addition to journal articles, books, book chapters, various contributions to periodicals, conference papers are also deposited, and for each publication it is necessary to define the access level and a license, so that the copyright is not infringed. Each record contains machine-readable Creative Commons licenses in line with the OpenAIRE repository guidelines. ${ }^{23}$ When depositing, the authors provide this information, and administrators perform additional checks in the original

$\overline{21}$ Information on journal policies as regards self-archiving can be found on the website SHERPA/RoMEO, (accessed on November 17, 2020).

22 Example of a publication containing links to related records - the peer-reviewed version and supplementary data, (accessed on November 17, 2020).

23 OpenAIRE Repository Guidelines License Condition, (accessed on November $17,2020)$ 
publication, on publishers' websites and/or in SHERPA/RoMEO during the verification step.

\section{External application for administrator}

This part of the paper presents the external applications developed by RCUB and their operation in combination with the DSpace software. Because items' metadata cannot be changed by users, the external applications perform operations that cannot be implemented or are difficult to perform in DSpace. The goals and benefits of this approach include metadata quality control, time savings, greater accuracy in handling metadata and easy metadata export.

\subsection{Authors, projects, publications (APP)}

Years ago, monitoring the scholarly work of all employees required a lot of time, keeping in mind that there was no unified system where complete data would be grouped. The primary function of the application Authors, projects, publications $^{24}$ is the creation of pages listing all records from the repository related to one author or project. Metadata download is also enabled for single records or groups of records. DSpace software versions 5 and 6 do not offer a number of options offered by APP, and DSpace 7 is still in beta. To meet a large number of users' requests, RCUB has developed this external application to enable metadata download according to various parameters.

By running search by author name or ORCID ID it is possible to obtain a complete bibliography of an author affiliated with the Faculty of Chemistry or the Innovation Center. ${ }^{25}$ ORCID is a register that assigns a unique and persistent identifier to researchers. Researchers can supplement their profiles with new papers manually or by downloading metadata from other databases. The selection of papers in APP can be limited using filters, i.e. according to the publication year, type, version (peer-reviewed or published), and based on the publication rank in the national research evaluation system used by MESTD - shown in Figure 1. Metadata are exported for individual records or groups of records in the RIS or BibTeX formats. The exported data may be imported into a reference manager where a bibliography is

$\overline{24}$ Authors, projects, publications, (accessed on November 17, 2020).

25 The completeness of bibliographies depends on the diligence of researchers in depositing their own papers in the repository. 
formed according to a desired citation style. Additionally, within the bibliography of author's works, the projects in which the author participated are presented, as well as those that are only mentioned in the publication. In order to retrieve a list of publications associated with a project, it suffices to enter a project code in the search field. Search results are accompanied with the list of all co-authors of the retrieved publications. The selection of papers is limited using filters, i.e. according to the publication year, type, version and the publication rank in the national research evaluation system used by MESTD.

The third segment of the application lists publications and citation counts. If a record is equipped with WoS and Scopus identifiers, the corresponding citation counts will be displayed next to the title in the list, and in addition to these two most well-known citation databases, Altmetric Attention Score and Dimensions citations are also displayed. The scores based on the weighted number of mentions on social networks, blogs, pages, are automatically calculated for each publication if the DOI is provided in the appropriate metadata field in the repository. It is possible to export metadata for all records in Cherry in RIS or BibTeX formats. It is possible to completely export all records from Cherry also in RIS or BibTeX format, and further narrowing the choice of works for export is equal to export by author name or by project name (by applying filters). Narrowing the selection of items for export is equal to the export by the name of the author or by the name of the project (by applying filters). The application is developed to meet users' requests. After the latest upgrade, it is possible to display and export publication metadata belonging to individual communities and collections in the repository. The application is the most appreciated at the time of preparing research progress reports because it is publicly available.

\section{$5.2 \quad$ Ellena}

Access to the application Ellena ${ }^{26}$ is limited to repository managers, i.e. those responsible for verifying deposits. This has been proven as a good practice because limited access prevents potential abuse. The application consists of three segments: Metadata Editor, Multiload and Administration. The first part of the Metadata Editor is used for mass changes of metadata, most commonly author names. Different versions of the name (written in different alphabets, with and without the middle initial, double surnames with and without hyphens, different surnames, etc.) are connected with the help of a

${ }^{26}$ Ellena, (accessed on November 17, 2020). 


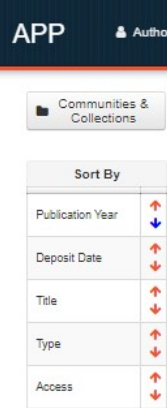

\begin{tabular}{|l|}
\hline Publication Year \\
\hline $2020(1)$ \\
\hline $2019(3)$ \\
\hline $2018(7)$ \\
\hline $2017(11)$ \\
\hline $2016(7)$ \\
\hline $2015(7)$ \\
\hline $2014(7)$ \\
\hline $2013(3)$ \\
\hline $2012(8)$ \\
\hline $2011(12)$ \\
\hline $2010(7)$ \\
\hline $2009(2)$ \\
\hline $2008(1)$ \\
\hline $2000(3)$ \\
\hline $2005(1)$ \\
\hline $2004(1)$ \\
\hline
\end{tabular}

\begin{tabular}{|l|}
\multicolumn{1}{|c|}{ Type } \\
\hline aticle $(70)$ \\
\hline other ( $(8)$ \\
\hline bookPart (1) \\
\hline doctoralThesis (1) \\
\hline
\end{tabular}

\section{Version publishedVersion (78) scceptedVersion (3)}

\begin{tabular}{|l|}
\multicolumn{1}{|c|}{ M-Rank } \\
\hline aM21 (2) \\
\hline aM21 (1) \\
\hline M21 (13) \\
\hline M22 (14) \\
\hline M23 (36) \\
\hline M23 (1) \\
\hline M24 (2) \\
\hline
\end{tabular}

Figure 1. Example of author bibliography

Vujisić, Ljubodrag V.

Link to this page

httos //cherry chem. bg. ac.rs/APP/faces/author.xhtml? author_id=orcid: 0000-0001-7625-

74348 item_offset $=0$ \& project_offset $=0$ \&sort_by $=$ do.date. issued

Authority Key $\quad$ Name Variants

orcid:0000-0001-7625-7484 • Vujisić, Ljubodrag V. (81)

Projects

search

Natural products of wild, cultivated and edible plants: structure Ontogenetic characterization of phylogenetic and bioactivity determination

biocivers ty

Sekundarni metaboliti samoniklih, lekovitih biljaka: izolovanje. Characterization and application of fungal metabolites karakterizacija i biloška aktivnost

Micromorphological, phytochemical and molecular

investigations of plants - systematic, ecological and applicative. Diversity of the flora and vegetation of the Centra aspects

The effects of magnetic fields and other environmental

stressors on the physiological responses and behavior of University of Graz

different species

Novel encapsulation and enzyme technologies for

Molecular characterization of bacteria from genera Bacillus and designing of new biocatalysts and biologically active Pseudomonas as potential agents for biological control compounds targeting enhancement of food quality.

Austrian Academy of Sciences at the Institute of Zoology. Department of Agricultural and Food Sciences. University of Graz [23811]

DOC fellowship of the Austrian Academy of Sciences, at the Federal Ministry of Education and Science project (the

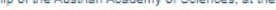
Institute of Zoology, University of Graz [23811]

Funkcionalna analiza ontogenetske diverzifikacije faune $i$ modifikacije evolutivnih odgovora tokom filogenije

European Commission

Molecular mechanisms of redox signalling in homeostasis: adaptation and pathology

Investigation on the medicinal plants: morphological, chemica! and pharmacological characterisation University of Bologna, Italy Federation of Bosnia and

Volkswagen Stitung

Advancing research in agricultural and food soiences at Faculty of Agriculture, University of Belgrade Study of structure-function relationships in the plant cell wall and modifications of the wall structure by enzyme engineering

The membranes as sites of interaction between the intracellular and apoplastic environments: studies of the bioenergetics and signaling using biophysical and biochemical techniques.

Traditional and new products of cultivated and wild growing fruits and grape vines, and by-products durring processing. with special emphasis on indigenous varieties: chemical characterization and biological profile

Biofizička istraživanja membranskih procesa: interakcija membranskin receptora i kanala sa spoljašnjim faktorima i intracelularna regulacija Ministry of Science and Environmental Protection of the Republic of Serbia

Geography of Serbia

Farmakodinamska i farmakogenetska istraživanja novih lekova i predikfivna/prognostička vrednost farmakoterapije u onkologiji

Author's Bibliography

RIS BibTeX $\leftarrow 1 / 81 \rightarrow$

Pygidial gland secretions of Carabus Linnaeus, 1758 (Coleoptera: Carabidae) chemirale roloaced hy threo enerioo 
local unique identifier in the form of an alphanumeric string. If the author has an ORCID ID, it is assigned instead of the local identifier generated by the software. In this way, in next to the name in Cherry, the ORCID logo is displayed, which links to the corresponding ORCID profile. Administrators continuously curate this database by finding ORCID IDs on the ORCID website, through communication with the authors and with the support of RCUB, through occasional notifications of newly registered ORCID IDs for individuals affiliated with the University of Belgrade - Faculty of Chemistry and the Innovation Center. For frequent names, it is technically possible to add the middle initial. Each name in Cherry is entered in the Latin script, regardless of how it is cited in the original publication. Linking names is additionally important for authors who have changed their last name. By linking the various versions of a name using a unique identifier, it is made possible to display all the publications of an author in a single list, which can further be exported to create a complete bibliography. Communication between researchers and administrators is necessary because the consolidation of author names is an ongoing process.

Each record in the repository has its own internal identifier in the form of an integer. Identifiers are assigned automatically and the most recent records have the highest numbers, sorted in descending order of entry as a useful tool for the administrator to have better visibility and data modification. Metadata Editor is searchable. Search can be limited to a specific collection and specific Dublin Core fields.

The second segment is Multiload, which enables metadata import from various sources. The most important options are DSpace Replicator, where metadata can be ingested into Cherry by copying the URL of a record from another DSpace repository, and RIS, where metadata is ingested from other databases using reference managers. Before ingesting metadata via DSpace Replicator, a whole set of metadata is displayed so that a repository administrator can make changes and corrections, if necessary. When using metadata retrieved from citation databases or publisher sites, greater care is taken because it is not always possible to optimally map the metadata fields in citation databases, reference managers and the repository. The Dublin Core metadata fields should be properly filled out in order to obtain detailed and complete metadata records enabling unambiguous identification of the publication. This ensures that users and aggregators are offered detailed, highquality and accurate metadata. Incorrect input can create confusion and lead to incorrect citation. Some of Dublin Core fields used in Cherry and other 
repositories developed by RCUB that comply with the OpenAIRE repository guidelines ${ }^{27}$ are shown in Table 1.

In the Administration segment of Ellena, the administrator is allowed to grant privileges to new members. At the University of Belgrade - Faculty of Chemistry, there are currently no interested parties, apart from librarians, who would take administration duties and ingest metadata through Ellena. This shortcoming can be overcome by hiring more librarians. A workflow involving one or more trained administrators within each department responsible for massive metadata ingestion could be adopted by the Faculty. In this case, the administrators would control what is published annually by researchers affiliated with the Faculty and the Innovation Center. Currently, researchers only deposit individual publications directly into the repository, in which they have support from the Library.

\subsection{NomadLite}

Application NomadLite ${ }^{28}$ aims to facilitate the curation of metadata relating to projects, Scopus and WoS identifiers and publication ranks used in the evaluation of scientific research at the national level. When depositing publications, researchers sometimes omit funding information. ${ }^{29}$ To ensure metadata accuracy and completeness, RCUB has developed a tool for repository administrators. NomadLite, shown in Figure 2, uses text mining to retrieve funding information. The identified information must be checked and verified by the administrator for each record separately.

Scopus and WoS identifiers do not need to be filled out manually during deposit (which would involve the manual searching of these databases). NomadLite uses APIs to retrieve these identifiers. With one click, the administrator verifies the identifier based on a comparative analysis of data from the citation database and Cherry (title, the name of the first author and publication year).

When manually depositing data, researchers are not offered the option to add publication ranks because this field is not provided in the repository software. The ranking of research results displayed in Cherry is defined by analysts for a specific research area at MESTD and is easily verifiable on

${ }^{27}$ OpenAIRE Repository Guidelines - Publication Type, (accessed on November $17,2020)$.

${ }^{28}$ NomadLite, (accessed on November 17, 2020).

${ }^{29}$ Data are downloaded from the address Nardus ProjectData.xml, (accessed on November 17, 2020). 


\begin{tabular}{|c|c|}
\hline dc.rights & Entered into field \\
\hline Open, free access & openAccess \\
\hline Closed access & closedAccess \\
\hline Restricted access & restrictedAccess \\
\hline Delayed open access & embargoedAccess \\
\hline dc.rights.license & Entered into field \\
\hline $\mathrm{CC} \mathrm{BY}$ & BY \\
\hline $\mathrm{CC}$ BY-SA & BY-SA \\
\hline CC BY-ND & BY-ND \\
\hline CC BY-NC & $\mathrm{BY}-\mathrm{NC}$ \\
\hline CC BY-NC-SA & BY-NC-SA \\
\hline CC BY-NC-ND & BY-NC-ND \\
\hline $\mathrm{CC} 0$ & 0 \\
\hline All rights reserved & ARR \\
\hline dc.type & Entered into field \\
\hline Journal article & article \\
\hline Bachelor's thesis & bachelorThesis \\
\hline Master's thesis & masterThesis \\
\hline Doctoral thesis & doctoralThesis \\
\hline Monograph & book \\
\hline Chapter in the monograph & bookPart \\
\hline \begin{tabular}{|c|} 
Reviews \\
\end{tabular} & review \\
\hline Conference paper & conferenceObject \\
\hline Lecture & lecture \\
\hline Working document & workingPaper \\
\hline Preprint & preprint \\
\hline Report & report \\
\hline Annotation & annotation \\
\hline Informative contribution & contributionToPeriodical \\
\hline Patent & patent \\
\hline Other & other \\
\hline dc.type.version & Entered into field \\
\hline Draft version & draft \\
\hline Unreviewed version & submittedVersion \\
\hline Reviewed version & acceptedVersion \\
\hline Published version & publishedVersion \\
\hline Corrected version & updatedVersion \\
\hline
\end{tabular}

Table 1. Full-text availability level 
Grape seed flour of different grape pomaces: Fatty acid profile, soluble sugar profile and nutritional value Milinňić, Danijel D.

IZABRANI PROJEKTI:

\section{REZULTAT PRETRAGE:}

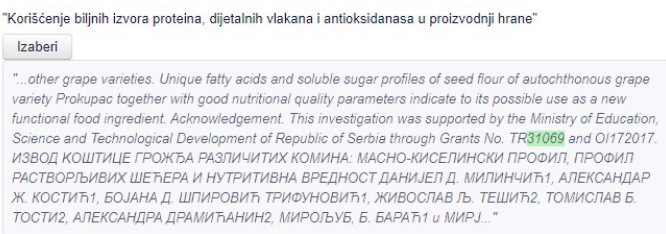

"Korelacija strukture i osobina prirodnih i sintetičkih molekula i njihovih kompleksa sa metalima" Izaberi

"...varieties. Unique fatty acids and soluble sugar profiles of seed flour of autochthonous grape variety Prokupac together with good nutnitional quality parameters indicate to its possible use as a new functional food ingredient. Acknowledgement. This investigation was supported by the Ministry of Education, Science and Technological Development of Republic of Serbia through Grants No. TR31069 and O/172017. И3BOL КОШТИЧЕ ГРОЖБА РАЗЛИЧИТИХ КОМИНА: МАСНО-КИСЕЛИНСКИ ПРОФИЛ, ПРОФИЛ

РАСТВОРЉИВИХ ШЕПЕРА И НУТРИТИВНА ВРЕДНОСТ ДАНИЈЕЛ Д. МИЛИНЧИЋ1, АЛЕКСАНДАР

Ж. КОСТИП 1, БОЈАНА Д. ШПИРОВИЛ ТРИФУНОВИЋ1, ЖИВОСЛАВ Љ. ТЕШИП2, ТОМИСЛАВ Б.

ТОСТИ2, АЛЕКСАНДРА ДРАМИЋАНИН2, МИРОЉУБ, Б. БАРАЋ1 Ч МИРЈАНА Б. ПЕШИЋ...

Figure 2. Machine-readable data for a number of project

ProRef information service. ${ }^{30}$ The repository administrator in the Cherry applies the existing publication ranking by transferring data from relevant sources, and the selection is made by reviewing the offered ranks in the application - shown in Figure 3. In case of papers published during the year for which Impact Factor is not yet announced, the administrator will assign a temporary rank, and the application assigns a tilde sign $(\sim)$. This makes it possible to filter publications with a temporary rank. After the new Impact Factors are published on the Journal Citation Report website, the administrator uses NomadLite to assign the final ranks.

${ }^{30}$ ProRef provides insight into the ranks of journals. The information service consists of three data sources: Journal Citation Report annual reviews, publication rank in the national evaluation system and lists of journals proposed by the faculties of the University of Belgrade in the field of social sciences and humanities: List of Journals, (retrieved on November 17, 2020) 
Saturation mutagenesis to improve the degradation of azo dyes by versatile peroxidase and application in form of VP-coated yeast cell walls

Ilić Đurđić, Karla (2020)

Enzyme and Microbial Technology (0141-0229)

dc. citation.rank

\begin{tabular}{|lllr|}
\hline Godina & Disciplina & Izvor & Ocena \\
\hline 2019 & Biotechnology \& Applied Microbiology & WoS & M22 \\
\hline 2018 & Biotechnology \& Applied Microbiology & WoS & M21 \\
\hline
\end{tabular}

Saturation mutagenesis to improve the degradation of azo dyes by versatile peroxidase and application in form of VP-coated yeast cell walls

Ilić Đurđić, Karla (2020)

Enzyme and Microbial Technology (0141-0229)

dc. citation. rank

\begin{tabular}{lllr}
\hline Godina & Disciplina & Izvor & Ocena \\
\hline 2019 & Biotechnology \& Applied Microbiology & WoS & M22 \\
\hline 2018 & Biotechnology \& Applied Microbiology & WoS & M21 \\
\hline
\end{tabular}

Figure 3. Publication ranking

\subsection{REPORTmakER (RM)}

The lists displayed in the application REPORTmakER ${ }^{31}$ help the administrator to control the quality of metadata:

- Records where full-text content is missing;

- Records where the document version name is missing;

- Journal articles where the ISSN information is missing;

- Records where the access information is missing;

- Records where the license information is missing;

- Books, book parts and conference papers without an ISBN;

- Book parts and journal articles where the title of the source publication is missing;

- Records where the publication year is missing.

ISSN and the availability of full text are particularly important. Without ISSN, in most cases, NomadLite would not be able to retrieve the information about the publication rank, which would result in incomplete lists

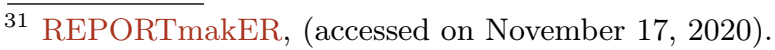


according to these ranks in APP. The availability of full text is the most important because it contributes to greater visibility and citation counts. REPORTmakER is the latest application which will be further improved and upgraded to enable even better metadata quality control. The current options have been developed based on repository administrators' observations related to the most common errors and omissions during deposit.

\section{Google Analytics}

Tracking the visits of Cherry is done using the free version of Google Analytics. The information available to administrators is:

- Real-time report - currently active users, page views and most active pages;

- Number of users, number of sessions, number of visits to one page only, duration of the session;

- Traffic channel, source from which users access the repository;

- Trend of activity during time of use;

- View user retention;

- Users by time of day;

- Sessions by country;

- Sessions per accessed device;

- Pages visited by users.

\begin{tabular}{|c|c|c|c|c|c|c|c|c|}
\hline Record & WoS & Scopus & Altmetric & Dimen. & Visits & Time & Year & Access \\
\hline 1. & 12 & 14 & - & 18 & 243 & $00: 02: 50$ & 2018 & Gold OA \\
\hline 2. & 9 & 16 & 1 & 20 & 209 & $00: 03: 25$ & 2016 & Gold OA \\
\hline 3. & 51 & 54 & 121 & 51 & 192 & $00: 01: 34$ & 2017 & Restricted \\
\hline 4. & 32 & 34 & 3 & 21 & 134 & $00: 01: 24$ & 2016 & Gold OA \\
\hline
\end{tabular}

Table 2. Citation analysis of the most visited records from April 2019 to October 2020

Each set of data can be limited to a specific period, which is set manually. Table 2 shows the overall performance from April 2019 to October 2020. The first four most visited papers are marked with the numbers ${ }^{32}$. The records

$\overline{32}$ 1. Microbial fertilizers: A comprehensive review of current findings and future perspectives 
are accompanied with the total number of citations in WoS and Scopus databases in Table 3, for the period from April 2019 to October 2020. An interesting presentation of the change in the number of citations and visits is reflected in the Table 4 because the data refer to the period before June 2020. In the time interval of only four months, all records show an increase in the number of citations, as well as in the number of visits in the repository.

\begin{tabular}{|c|c|c|c|c|c|c|c|c|}
\hline Record & WoS & Scopus & Altmetric & Dimen. & Visits & Time & Year & Access \\
\hline 1. & 9 & 13 & - & 14 & 185 & $00: 02: 25$ & 2018 & Gold OA \\
\hline 2. & 6 & 12 & 1 & 17 & 185 & $00: 04: 07$ & 2016 & Gold OA \\
\hline 3. & 36 & 43 & 124 & 42 & 183 & $00: 01: 35$ & 2017 & Restricted \\
\hline 4. & 27 & 31 & 3 & 20 & 132 & $00: 01: 24$ & 2016 & Gold OA \\
\hline
\end{tabular}

Table 3. Citation analysis of the most visited records from April 2019 to June 2020

Google Analytics does not track visits to deposited files, but only to the landing pages with metadata. Keeping this in mind, it may be concluded that the total number of visits is significantly greater than the data displayed in Google Analytics. In the coming period, more attention will be paid to the development of a system for monitoring content traffic in the repository.

\section{Conclusion}

The presented achievements indicate the comprehensiveness of repositories for scholarly publications, which conform to clearly defined guidelines and rules. Each rule was tested before it was introduced in order to provide the highest possible effect based on the developed European and other international repositories using the same software. Given that new records are added on a daily basis, in the future, the picture of the scientific work at the University of Belgrade - Faculty of Chemistry, and the Innovation Center will be even more complete. The improvements of the system, monitoring

2. Antifungal and antibacterial activities of Petroselinum crispum essential oil

3. Design of coiled-coil protein-origami cages that self-assemble in vitro and in vivo

4. Equilibrium solubility measurement of ionizable drugs - consensus recommendations for improving data quality 


\begin{tabular}{|c|c|}
\hline \multirow[t]{4}{*}{ Number of users } & Total about 6,722 \\
\hline & 5,577 via computer \\
\hline & 1,118 via mobile phones \\
\hline & 46 via tablet \\
\hline \multirow[t]{4}{*}{ Number of sessions } & Total about 14,551 \\
\hline & 12,499 via computer \\
\hline & 2,003 via mobile phones \\
\hline & 49 via tablet \\
\hline Number of visits to only one page & $48,37 \%$ \\
\hline Session duration & 35 min. 47 sec. \\
\hline New Visitors & $87 \%$ \\
\hline Returning Visitors & $13 \%$ \\
\hline \multirow[t]{10}{*}{ Visits from the top ten countries } & Serbia: 3,097 users (45.73\%) \\
\hline & Germany: 437 users $(6.45 \%)$ \\
\hline & United Kingdom: 347 users $(5.12 \%)$ \\
\hline & India: 185 users $(2.73 \%)$ \\
\hline & China: 177 users $(2.61 \%)$ \\
\hline & Turkey: 157 users $(2.32 \%)$ \\
\hline & Brazil: 131 users $(1.93 \%)$ \\
\hline & Bosnia \& Herzegovina: 115 users $(1.70 \%)$ \\
\hline & Iran: 96 users $(1.42 \%)$ \\
\hline & Japan: 91 users (1.34\%) \\
\hline \multirow[t]{6}{*}{ Browsers } & Chrome: 4,799 users $(71.19 \%)$ \\
\hline & Firefox: 820 users $(12.16 \%)$ \\
\hline & Safari: 362 users $(5.37 \%)$ \\
\hline & Edge: 196 users $(2.91 \%)$ \\
\hline & Opera: 111 users $(1.65 \%)$ \\
\hline & Others: $6.02 \%$ \\
\hline \multirow[t]{6}{*}{ Operating Systems } & Windows: 5,018 users (74.43\%) \\
\hline & Android: 931 users (13.81\%) \\
\hline & Macintosh: 320 users $(4.75 \%)$ \\
\hline & iOS: 224 users $(3.32 \%)$ \\
\hline & Linux: 116 users $(1.72 \%)$ \\
\hline & Others: $0.07 \%$ \\
\hline \multirow[t]{3}{*}{ Sessions per device } & Computers: $82.73 \%$ \\
\hline & Mobile Phones: $16.59 \%$ \\
\hline & Tablet devices: $0.68 \%$ \\
\hline Most Active Users & Wednesdays from $10 \mathrm{AM}$ to $3 \mathrm{PM}$ \\
\hline
\end{tabular}

Table 4. Records attendance analysis 
and innovations in the communication between librarians and developers increase the overall added value that Cherry brings to the institution.

\section{References}

Fry, Jenny, Valérie Spezi, Stephen Probets and Claire Creaser. "Towards an understanding of the relationship between disciplinary research cultures and open access repository behaviors". Journal of the Association for Information Science \& Technology Vol. 67, no. 11 (2016): 2710-2724. https://doi.org/10.1002/asi.23621

Gibbons, Susan. "Defining an Institutional Repository", Library Technology Reports Vol. 40, no. 4 (2004): 6. https://journals.ala.org/index.php/ ltr/article/view/4378

Kosanović, Biljana, Vasilije Rajović, Obrad Vučkovac and Milica Ševkušić. "EIFL Webinar: Enrich your DSpace repository with customized tools", 2020. https://www. youtube.com/watch?v=_sL948EaJxI

Kruesi, Lisa, Kerry Tanner, Frada Burstein, Maria G. N. Musoke, Martin Morris et al.. "Advancing scholarly publishing through open access biomedical repositories: A knowledge management perspective". IFLA Journal Vol. 45, no. 3 (2019): 233. https://doi .org/10.1177/0340035219846139 Kurtz, Mary. "Dublin Core, DSpace, and a Brief Analysis of Three University Repositories". Information Technology \&6 Libraries Vol. 29, no. 1 (2010): 40-46. https://doi.org/10.6017/ital.v29i1.3157

Rajović, Vasilije, Biljana Kosanović and Milica Ševkušić. "DSpace - institutional repositories - dissemination of research results: A local case study", 2018. https://doi.org/10.5281/zenodo.1411159

Ševkušić, Milica, Zorica Janković and Aleksandra Kužet. Open Access Journals in Serbia: Policies and Practices. National Library of Serbia Belgrade, 2017. https://doi.org/10.5281/zenodo. 801673

Ђенадић, Борис, Татјана Тимотијевић and Катарина Перић. "КоБСОН на међународној сцени". Библионет, Сарадња и партнерства: креирање нове заједничке визије за библиотеке, 2020

Тимотијевић, Татјана, Жељко Димитријевић and Катарина Перић. "КоБСОН 24/7". In Виртуелна култура : зборник радова. Къ. 1 / 15. Међународна научна конферениија, Београд, 23-25. септембар 2016., Вранеш, Александра and Љиљана Марковић, MELISSA Museums, Ethics, Library and Information Science, Studies, Archives, Vol. 15, 197-211. Београд: Филолошки факултет, Универзитет у Београду, 2016. http://doi.fil.bg.ac.rs/pdf/eb_ser/melissa/ 2016-1/melissa-2016-15-1-ch17.pdf 